\title{
The Innovation In Education of Islamic Boarding School Through The Use of E-Learning
}

\author{
R Setyaningsih ${ }^{1}$, Abdullah $^{2}$, E Prihantoro $^{3}$, Hustinawaty $^{4}$ \\ University of Darussalam Gontor ${ }^{1,2}$, University of Gunadarma ${ }^{3,4}$ \\ \{rilasetya@unida.gontor.ac.id ${ }^{1}$, abdullah@unida.gontor.ac.id², edipri@staff.gunadarma.ac.id ${ }^{3}$, \\ hustina@staff.gunadarma.ac.id $\left.{ }^{4}\right\}$
}

\begin{abstract}
Islamic boarding schools that have been using the textual learning model for a long period of time are now facing new challenges in what is referred to as the industrial revolution 4.0. Islamic boarding schools are required to adapt to the contextual learning model through educational technology innovation. The purpose of this study is to analyze the innovation in education at the Islamic boarding school-based college. The method used for this research was qualitative, and data collection was made through observation and interviews with five different subject lecturers. The results of this study indicate that one form of educational innovation conducted by islamic boarding school is through the development of e-learning. The direction of educational innovation consists of four steps: invention, development, diffusion, and adaption. The contribution of this study is the proposed innovation in education at the islamic boarding school, through the use of e-learning.
\end{abstract}

Keywords: E-learning, Innovation, Education, Islamic Boarding School.

\section{INTRODUCTION}

The emergence of the industrial 4.0 era brought a wide spectrum of changes in many sectors, including that of education [1]. The increasingly sophisticated development of educational technology is considered a challenge for Islamic boarding schools, as they are required to make adjustments to both the curriculum and teaching approaches. There is an urgent need to adapt and implement the most modern learning strategies in order to keep up with the ever-developing cyber world, otherwise the competitiveness for Islamic boarding schools will become increasingly weak due to lack of modernization. Updating learning methods could improve the competitiveness and quality of graduates in the workplace and society, as well as better equip students with the necessary knowledge to excel in the new age.

The results of preliminary observations show that the textual learning model still dominates the learning system in the Communication Studies Program at the University of Darussalam Gontor in Indonesia. The use of contextual learning models is limited even though it is considered an essential tool in teaching; student reasoning is more developed as they are given the opportunity to construct ideas according to their abilities [2]. Furthermore, educational technology innovation is now a demand in modern boarding schools in order to increase competitiveness, as has been done in the past. Modern boarding schools have previously made fundamental changes due to observing weaknesses in traditional Islamic boarding school education - for example, the Islamic curriculum only teaches religion-based 
information, limiting the scope of jobs graduates can apply to due to lack of general knowledge, technology mastery and niche skills [3]. The use of digital media in learning is an easy way to introduce technology to students. Digital media can not only present learning material contextually, but provide an interactive and dynamic experience through exciting audio and images/videos [4]. The use of digital media is also expected to improve students' understanding of learning material.

Educational technology as a medium of teaching is important in addressing the challenges as well as creating opportunities for Islamic boarding schools, specifically with gaining a competitive edge among other educational institutions. When Islamic boarding school communities can master technology while still having a strong foundation in religion, the moral degradation and the destruction of ethics due to the negative impact of media and technology can be reduced, and eventually solved. The most severe challenge of modernity is the shift of values and morals influenced by globalization, the increase of consumerism, and people's dependence on modern technology [5]. Islamic boarding schools must take it upon themselves to create solutions for these challenges.

Educational innovation is developed to constantly progress the field and achieve specific goals while solving any issues that arise. A study of innovation in education was conducted by Lahinta with the aim of investigating the best learning model in promoting innovation within the education system. The results concluded that e-learning, distance learning, and the multimedia classroom are all systems that can increase innovation, without the need for lecturers and students depending on distance, space and time in order to interact [6]. Nurryna also carried out research which suggested that more progress in the development of information and communication technology increases the certainty of teaching and learning activities with a variety of educational media [7]. In line with the two results mentioned, this study is trying to explore the use of digital media in conducting educational innovations. The direction of educational innovation consists of four steps: invention, development, diffusion, and adaption [8].

This topic needs to be studied as it is important in supporting the policy of the Ministry of Communication and Information of the Republic of Indonesia delivered in Press Release No. 04 / SP / HM / BKKP / I / 2018 concerning Science and Technology Development and Higher Education in the Era of the Industrial Revolution 4.0 [9]. In order to support government policy, this study aims to examine the direction of innovation in boarding education at the Communication Studies Program, at the University of Darussalam Gontor.

\section{RESEARCH METHOD}

This study uses a descriptive qualitative method to analyze the direction of educational innovation. The data in this study was obtained through direct observation of the uses and effects of e-learning, and in-depth interviews with policymakers. After conducting in-depth observations and interviews, the researcher constructed the information obtained and mapped the direction of innovation carried out by Communication Science Study Program. Data analysis techniques are based on Miles and Huberman's theory, using data reduction, display, and conclusions to gather results [10]. Reduction is conducted by summarizing, condensing the information, and then focusing on the key points. Presentation of data comes in the form of brief descriptions and analysis of relationships between categories, etc. Summarizing conclusions from the data is the last step in data analysis. The validity of the research data is formulated through triangulation, in which the data is tested for validity [11]. Data collection techniques are combined with various existing techniques and data sources. Triangulation of 
data in this study combines observation and interview techniques, and source triangulation is accrued through data sources from several research subjects.

\section{RESULT AND DISCUSSION}

This study has analyzed the direction of educational innovation in the Communication Studies Program at the University of Darussalam Gontor. Educational innovation can be interpreted as a new method to improve the ability to achieve educational goals [12]. This study was examined using four aspects of innovation: invention, development, diffusion, and adaption.

Invention is a discovery/creation of something new. Based on the results of the study, inventions that occur in the Communication Studies Program are in the form of five basic subjects, specifically: 1) Introduction to Communication Science, 2) Communication Theory, 3) Communication Psychology, 4) Mass Communication and 5) Contextual Communication, all of which are uploaded on an e-learning site. The creative and innovative learning content that was previously discovered did not exist, but then it was developed with new creations from the instructors of the basic courses at the Communication Studies Program. This is in line with Hasan's research, which states that invention is the discovery of something that is truly new as a result of human creation, objects or things that were discovered (did not exist) previously, then made with the results of new creations, such as the discovery of learning theory, educational theory, the technique of making plastic goods, fashion clothing, etc [13]. The emergence of fresh and creative ideas are the result of observations and experiences of the learning process that had already existed, but the forms that were found were completely new.

The second stage of educational innovation is development. The results obtained suggested that this stage was carried out through the development of learning content consisting of lecture material, pre-test/post-test questions, and virtual discussion forums. Media development and further testing were carried out on media produced in the form of e-learning. E-learning is teaching and learning that uses electronic circuits (LAN, WAN, or the internet) to provide alternative forms of teaching [14]. It was created in 2018 off the basis of Moodle. Development of e-learning in the first year is limited to five basic courses, then developed for other subjects in the following year after being tested and evaluated.

Diffusion is the third stage of educational innovation. A form of communication, it is considered unique, relating to the dissemination of messages in the form of new ideas, or as Rogers (1983) suggested, diffusion is the " the spread of new ideas from the invention or creation to its ultimate users or adopters" [15]. The diffusion of learning innovation carried out by the Communication Studies Program at the University of Darussalam Gontor experienced several processes, including awareness in 2016, when a workshop was held on the Qualification of Indonesian National Competencies by the university. The second process of interest was the variety of information gathered through several workshops on learning methods. The next step in diffusion is an evaluation, which is the emergence of several conflicts and negotiations related to the learning model more appropriate to boarding-based colleges. A trial was conducted for e-learning with five lecturers in the basic course of Communication Studies at the University of Darussalam Gontor, and the latest e-learning media adoption in mid-2018.

The last stage of educational innovation is adaption. It is the stage in which the Communication Study Program accepted and adapted to the new learning media technology in the form of e-learning, composing creative and innovative learning content using the contextual modules. This form of learning encourages students to understand the reality, 
meaning, and benefits of studying, so that they are more diligent and motivated to learn, even almost addicted to learning, these conditions are realized when students are aware of what they need to live, and how to achieve it [16]. With the help of e-learning media, learning activities are expected to increase the participants' understanding of the material to produce optimal output.

Innovation in the Communication Studies Program at the University of Darussalam Gontor does not 'just happen'. When the innovation began to be applied, problems arose in its implementation, where it was initially being managed by PPTIK University of Darussalam Gontor, which then entirely delegated the project to the manager of Communication Science Study Program. In technological capability, the manager of the Communication Science study program does not have sufficient knowledge regarding the management of e-learning as an innovative product produced. On the other hand, face-to-face learning models that have been built for a long time in boarding schools, have become a socio-cultural obstacle for lecturers to implement e-learning even though they have obtained approval from the university leader [17].

\section{CONCLUSIONS}

This study analyzes the Islamic boarding education conducted by the Communication Studies Program at the University of Darussalam Gontor. Educational innovation is enforced through invention, development, diffusion, and adaptation through e-learning. Research recommendations are given to the administrators and stakeholders in special Islamic boarding schools at University of Darussalam Gontor to implement education through the use of elearning.

\section{ACKNOWLEDGMENT}

Ministry of Research, Technology and Higher Education, Director General of Development and Research Enhancement of the Republic of Indonesia and University of Darussalam Gontor.

\section{REFERENCES}

[1] S. Priatmoko, "Memperkuat Eksistensi Pendidikan Islam Di Era 4.0," TA'LIM J. Stud. Pendidik. Islam, vol. 1, no. 2, pp. 1-19, 2018.

[2] J. Sulianto, "Keefektifan Model Pembelajaran Kontekstual dengan Pendekatan Open Ended dalam Aspek Penalaran dan Pemecahan Pada Materi Segitiga di Kelas VII," Ilmu Pendidik., vol. 17, no. 6, pp. 454-458, 2011.

[3] M. Nurhakim, "Imam Zarkasyi Dan Pembaharuan Pesantren: Rekonstruksi Aspek Kurikulum, Menejemen Dan Etika Pendidikan,” Progresiva, vol. 5, no. 1, pp. 83-96, 2011.

[4] I. Umam, Kaiful; Zaini, "Penerapan Media Digital Dalam Pembelajaran Apresiasi Batik Kelas X SMA Negeri 1 Blega,” J. Pendidik. Seni Rupa, vol. 1, no. 1, pp. 100-105, 2013.

[5] M. Jamaluddin, "Metaorfosis Pesantren Di Era Globalisasi," KARSA J. Sos. dan Budaya Keislam., vol. 20, no. 1, pp. 127-139, 2012.

[6] A. Lahinta, "Berbagai Model Inovasi Pembelajaran dengan dukungan Teknologi Informasi," in Seminar Internasional APTEKINDO, 2012, pp. 9-15. 
[7] A. F. Nurryna, "Pengembangan Media Pendidikan Untuk Inovasi Pembelajaran," $J$. Speed, vol. 1, no. 2, pp. 1-5, 2009.

[8] Rusdiana, Konsep Inovasi Pendidikan. Bandung: Pustaka Setia, 2014.

[9] Kementerian Komunikasi dan Informatika Republik Indonesia, "Siaran Pers No.04/SP/HM/BKKP///2018 tentang Pengembangan Iptek dan Pendidikan Tinggi di Era Revolusi Industri 4.0," 2018.

[10] I. H. Tamin, "Peran Filantropi dalam Pengentasan Kemiskinan di dalam Komunitas Lokal," J. Sosiol. Islam, vol. 1, no. 1, pp. 35-58, 2011.

[11] B. S. Bachri, "Meyakinkan Validitas Data Melalui Triangulasi Pada Penelitian Kualitatif," J. Teknol. Pendidik., vol. 10, no. 1, pp. 46-62, 2010.

[12] N. Asiah, "Evaluasi Pelaksanaan Pembelajaran E-Learning di SMA Budaya Bandar Lampung," CIRCUIT J. Ilm. Pendidik. Tek. Elektro, vol. 1, no. 2, pp. 166-176, 2016.

[13] M. Hasan, "INOVASI DAN MODERNISASI PENDIDIKAN PONDOK PESANTREN,” KARSA J. Sos. dan Budaya Keislam., vol. 23, no. 2, pp. 295-305, 2016.

[14] M. Yazdi, "E-learning sebagai Media Pembelajaran Interaktif Berbasis teknologi Informasi," J. Ilmua Foristek, vol. 2, no. 1, pp. 143-152, 2012.

[15] S. Setyawan, "Pola Proses Penyebaran dan Penerimaan Informasi Teknologi Kamera DSLR," Komuniti, vol. 9, no. 2, pp. 146-156, 2017.

[16] A. Haryono, "Authentic Assessment dan Pembelajaran Inovatif dalam Pengembangan Kemampuan Siswa," J. Pendidik. Ekon., vol. 2, no. 1, pp. 1-12, 2009.

[17] K. Saddhono, "Cultural and social change of foreign students in Indonesia: The influence of Javanese Culture in Teaching Indonesian to Speakers of Other Languages (TISOL)." IOP Conf. Ser.: Ear. and Envi. Sci.. vol. 126 no. 1 IOP Publishing, 2018. 